\title{
Beyond good teaching practices: Language teacher leadership from the learners' perspective
}

Teacher leadership has been given increased recognition in general education as a means to empower teachers as professionals and improve educational outcomes. However, it has not received as much attention in the field of English Language Teaching (ELT), and research that has been conducted in this area has tended to focus predominantly on program management. This study chose to focus on examining learners' perspectives of language teacher leadership with the aims of contributing to a more complete conceptualization of teacher leadership in ELT. Twenty Korean university students were interviewed to explore their opinions of what language teacher leadership entails in terms of teacher practices and characteristics. The findings revealed an ensemble of qualities under the categories of Passion, Rapport, Purpose, and Balance \& Flexibility that learners believe to be essential to language teacher leadership. The findings also indicate that learners' ideas about leadership in the language classroom go beyond classroom practices, are distinct from traditional views of leadership, and also differ from the way in which many language teachers see leadership in their classrooms.

Given the rapid expansion and change in English language teaching (ELT) contexts and the evergrowing diversity of learners, arguably some of the most essential qualities teachers can possess include a sense of empowerment in their classrooms and schools (Lieberman \& Miller, 2004; McGee, Haworth, \& MacIntyre, 2015), and an understanding of how to appreciate and inspire students as individuals. Thus, it is unsurprising that in recent years there has been increased interest in the topic of leadership in the field with the hopes of strengthening professionalism by placing more attention on teachers' evolving roles both inside and outside the classroom (see Christison \& Murray, 2009; Coombe, McCloskey, Stephenson, \& Anderson, 2008; Fenner, 2016; Greenier \& Whitehead, 2016). This development has led to an emerging discussion about the importance of teacher leadership as an essential component in ELT, with increasing recognition that a focus on fostering the understanding and growth of leadership skills can make invaluable contributions to successful teaching and learning (Coombe et al., 2008).

While there has been an explosion of research on teacher leadership in general education (see Berry, Daughtrey, \& Wieder, 2010; Curtis, 2013; Lieberman \& Miller, 2004), the concept remains 
nascent in the ELT context, despite a growing call for more research on the topic (Christison \& Murray, 2009; Shields \& Sayani, 2005). At present, the majority of existing literature on leadership in ELT has been concerned with program management, organizational structure, and other aspects of administration (Christison \& Murray, 2009; Coombe et al., 2008; Muijs \& Harris, 2003; Pennington \& Hoekje, 2010; White, Hockley, van der Horst Jenson, \& Laughner, 2008), while few studies have examined language teacher leadership at the classroom level. This may in part be due to the presumed overlap of the concepts of good teaching and good leadership, where the latter may be viewed as a naturally embedded component of effective instruction and interpersonal behaviour (see, for instance, Wei, Den Brok, \& Zhou, 2009; Wubbels, Brekelmans, den Brok, \& van Tartwijk, 2006). Although we acknowledge that the concepts are interrelated, we firmly believe that further attention needs to be given to leadership in its own right to understand better what it entails and how it relates to language teaching practices.

\section{THEORETICAL BACKGROUND}

Educational leadership is a complex process that is both culturally and contextually bound (Dimmock \& Walker, 2005), yet despite its definitional ambiguity, there seems to be widespread agreement regarding its importance for enhancing educational outcomes. Studies from diverse countries and contexts have found a strong relationship between students' success and leadership (Christison \& Lindahl, 2009; Hargreaves \& Fink, 2004; Wong \& Evers, 2001). In addition, there has been a growth in special interest groups in leadership (Murphy, 2005; Stephenson, 2008), and in recent years, leadership has become a component of some Teaching English to Speakers of Other Languages (TESOL) qualifications, such as TESOL International Association's Leadership Management Certificate Program (LMCP) (2018) and the Oxford TEFL Course entitled Leadership in ELT (2018). However, Coombe et al. (2008) argue there is still a lack of material on the theory and practical application of leadership in the field of TESOL. Again, this may be because there is not yet a clear understanding of where leadership is located, and because a concrete definition of the concept has proven somewhat elusive.

\section{Defining teacher leadership}

Teacher leadership has taken on a broad range of meanings in educational research over the past decade (Ackerman \& Mackenzie, 2006; Katzenmeyer \& Moller, 2009; Wenner \& Campbell, 2017), 
in part because it is often used as an umbrella term for various dimensions of leadership enacted by teachers in their classrooms and schools (York-Barr \& Duke, 2004). Many of the definitions have positioned it as something teachers do in the broader school context that contributes to shaping the learning culture, such as acting as a mentor to other teachers, and influencing educational improvements within their schools (Katzenmeyer \& Moller, 2009). Killion and Harrison (2006) suggest additional roles such as instructional and curriculum specialist, resource provider, learning facilitator, school leader, and catalyst for change, among others. Some scholars have suggested that it entails even more intensive roles, such as being involved in policy matters (Margolis \& Huggins, 2012; Muijs \& Harris, 2003), and being partly responsible for change in the whole school organization (Carpenter \& Sherretz, 2012; Vernon-Dotson \& Floyd, 2012).

In an effort to locate teacher leadership as an independent trait, Crowther, Ferguson, and Hann (2009) submit pedagogical expertise, professionalism, enthusiasm, passion, and commitment as essential qualities of teacher leadership; characteristics which apply to both inside and outside the classroom. In a survey of school administrators' perspectives on what constitutes good leadership in teachers, Watt, Mills, and Huerta (2010) found that administrators drew particular attention to ". . classroom environment attributes, such as being an excellent teacher, having great rapport with students, and demonstrating high expectations for students" (p. 57). Others have situated teacher leadership in terms of actions and behaviors carried out in the classroom through teaching and interpersonal interaction with students (see, for example, Greenier \& Whitehead, 2016).

It is now widely understood that the process of teaching is embedded in a web of social constructs and that usable knowledge in teaching requires knowledge not only about oneself as a teacher but also knowledge of the learners and the context (Clandinin \& Connelly, 1995; Johnson \& Ma, 1999; Telles, 2000). Therefore, the perspective in this study emphasizes that understanding language teacher leadership requires a contextualized account of classroom interaction and an explication of the ways in which all individuals - students and teachers - are situated and engaged in the process of learning. In other words, we define teacher leadership as a dynamic set of qualities, characteristics, and behaviors exhibited inside and outside the classroom which positively influence learners not only in their learning, but also in their lives.

\section{Teacher leadership models}

Over the years, a number of teacher leadership theories have been moulded and amalgamated for application in education. The models that have become most pervasive in the educational 
leadership literature, and that most closely align with the values stated in the definition above, are servant leadership (Kiersch \& Peters, 2017; Wheeler, 2011), transformational leadership (Anderson, 2017), authentic leadership (Begley, 2001; Kiersch \& Peters, 2017), and distributed leadership (Harris, 2013). The shared characteristic of these models is that they advocate for empowering all members of an organization. The first, servant leadership, has become prevalent in the educational sector since publication of Wheeler's 2011 influential book, Servant Leadership for Higher Education: Principles and Practices. The book expounds on the need for a collaborative environment in educational institutions and stresses that leadership entails service rather than control. Transformational, authentic, and distributed leadership models, all of which are included in Bush \& Glover's (2014) comprehensive review of the theoretical literature on current models of school leadership, describe leaders as those who cultivate integrity throughout the organisation by exemplifying it themselves; inspire and motivate 'followers' through their actions; and involve others in the decisions that affect them. It may be helpful to briefly elaborate on each of these models given their influence on current trends in school leadership philosophies.

Servant leadership entails that the needs of those served are prioritized; it begins with a leader who wishes to serve others and to share responsibility rather than assume it. Servant leadership asks the question, "Do those served grow as persons? Do they, while being served, become healthier, wiser, freer, more autonomous, more likely themselves to become servants?" (Greenleaf, 2007, p. 6). The leader's focus is primarily on the growth and well-being of the people and community they serve.

Transformational leadership engages in a journey with followers, endeavours to raise consciousness about the significance of desired outcomes, focuses on higher intrinsic needs, and creates a clear vision for the future (Judge \& Piccolo, 2004). In this model, a leader is defined by four elements: idealized influence (acts as a role model); intellectual stimulation (provides support and encourages autonomy); inspirational motivation (inspires by instilling confidence, motivation, and purpose); and individual consideration (treats others as individuals with unique needs) (Bass, 1985).

Authentic leadership places an emphasis on leadership being constructed with followers through ethical, honest relationships, and genuine actions. Authentic leaders build their legitimacy through compassion, a sincere concern for others, and consistency in their behaviour (Bhindi \& Duignan, 1997). An important dimension of authentic leadership is that it is not predicated on power and authority, but on credibility and trust bestowed by followers; hence it requires a ceaseless sense of 
integrity and responsibility (George, 2010; Walumbwa, Avolio, Gardner, Wernsing, \& Peterson, 2008).

Finally, distributed leadership focuses on where responsibility is located and how it is exercised in the organizational environment (Leithwood, Muscall, \& Strauss, 2009). It stresses interdependent action focused on expertise rather than position, and involves all individuals that wish to contribute to a positive environment through continuous communication and development (Harris, 2013).

There are numerous other teacher leadership models that have been proposed for the field of education, and scholarly work continues to synthesize major concepts into composite models so that they may be more readily applied in practice. However, for the most part, the focus on developing teachers as leaders exists in the arena of general education, and little attention has yet been given to teacher leadership in the specific context of English language education, especially in terms of instructing English language learners (Greenier \& Whitehead, 2016; Baecher, Knoll, \& Patti, 2013; McGee et al., 2015).

\section{Teacher leadership in English language teaching}

In a theoretical critique of leadership in ELT today, Underhill (2005) argues that we need to advance from traditional dominance models and hierarchical conceptualizations of leadership to a more horizontal kind of leadership which is premised on relationships of trust, shared learning, and a commitment to improvement and development. However, few studies have been conducted that focus on conceptualizing what language teacher leadership may actually entail within the classroom.

One of the few studies that has focused directly on language teacher leadership was conducted by Greenier and Whitehead (2016). In their study, they asked EFL teachers to describe the competencies and actions they associate with leadership in the classroom. They found that most participants tended to emphasise the organizational, managerial, and pedagogical attributes of leadership, although they did call also attention to personal qualities such as being patient, empathetic, passionate, and acting as a role model for learners. Although this study shed some light on the issue of what language teacher leadership may entail, it was limited only to teachers' self views.

As ELT teachers' work becomes increasingly more complex, it is crucial that they are equipped with the skills and knowledge to be a good leader in a myriad of situations. Therefore, additional 
research from different stakeholders' perspectives is paramount to provide a more detailed and multidimensional description and understanding of exactly what leadership involves and its practical implications for English language education.

\section{AIM AND QUESTIONS ADRESSED}

In recognizing language teacher leadership as socially constructed, this study gives impetus to the voices of students, crucial yet often neglected stakeholders in educational research and school improvement. By examining language teacher leadership from the learners' vantage point, we hope to advance the recognition, understanding, and research of language teachers as leaders first and foremost in their classroom. In acknowledging the interpretive nature of this study, qualitative methods were selected to explore, understand, and provide a detailed account of learners' perceptions (Creswell \& Creswell, 2017).

The following research questions provided the basis for this exploratory study:

RQ 1: In what ways do learners see language teachers as leaders?

RQ 2: From the learners' vantage point, what specific (personal and pedagogical) features and characteristics contribute to good language teacher leadership?

\section{THE CONTEXT OF THE STUDY}

Anderson (2009) asserts that leaders should not be defined by their title or position but rather by their behaviours and characteristics. While we agree with this definition, it is important to note that in some countries like South Korea (hereafter Korea), leadership roles have historically been tied to one's role or position. Thus, in the context of this study it is essential to discuss how leadership has traditionally been defined or viewed to better understand present leadership values within the country.

\section{Cultural context}

Korea has experienced various political forms and philosophical concepts of leadership (Cumings, 2005), all having influenced the way in which leadership is perceived today. One of the largest influences on Korean culture, society, and education has been Confucianism, which continues to affect current customs, practices, and ideologies (Lee, 2001, 2006). Although various Confucian 
beliefs and practices have changed or disappeared over time (Yi \& Douglas, 1967), some general principles remain ingrained within the Korean education system (Robertson, 2002), possibly affecting how language teacher leadership is viewed. One notable Confucian influence on leadership is the system being hierarchically structured so that those in higher positions hold power over those below them (Lee, 2001). Within this top-down system, authoritarian style leadership tends to dominate over other styles previously discussed.

Authoritarian leadership generally refers to a leadership style in which an individual in control assumes resolute authority over subordinates and expects loyalty and obedience (Cheng, Chou, Wu, Huang, \& Farth, 2004). Relating this to the higher education situation in Korea, Lee (1999) explains that the historical Confucian precedence of authoritarian bureaucracy in society and education creates a structure in which faculty members see themselves as subordinate to administrators and students perceive themselves as being under the supervision of their instructors, although, in both cases, this has traditionally been accepted as a moral obligation and respect rather than coercion. While deference to elders and superiors remains an important value in Korean society, Lee $(1999,2001)$ points to a need for contemporary reforms to establish an organizational culture which is more inclusive of all stakeholders' views. In the current system, teachers, who are almost always near the bottom of the hierarchy, often have very little influence on what goes on outside their classrooms and are constrained by the decisions of those above them, largely because cultural norms in Korea make most teachers reluctant to challenge the authority of their superiors (Cho \& Bong, 2013; Kumaravadivelu, 2008).

Hence, many teachers in Korea may consider those in higher administrative positions as the authoritarian leaders in their schools, which may influence the degree to which they regard themselves as leaders, as well as how they develop, integrate, and convey their own leadership philosophy to students in their classroom practices. Indeed, social ideologies and experiences combined with this top-down hierarchical system can have a profound influence on teachers' and students' perceptions of language teacher leadership, as can classroom experiences.

\section{Educational context}

The differing roles, leadership styles, and classroom practices of language teachers at different educational levels (elementary, middle school, high school, and university) in the Korean context may also affect the way in which language teacher leadership is perceived by learners. In elementary school, teachers tend to lead classes in a playful manner focusing on improving 
learners' overall communicative competence (see Moodie \& Nam, 2016). However, in middle school, the focus begins to shift towards preparation for the College Scholastic Ability Test (CSAT), and entrance into university (Whitehead, 2016; Kim \& O, 2002). By late middle school and into high school, English language learning tends to become dominated by memorization of grammar rules, lexis, and mock CSAT test practice (Choi, 2008; Moodie \& Nam, 2016). The diversity in teacher roles and leadership styles that learners experience in Korean English language classrooms over time, combined with the systematic structuring of leaders within the education system, provide a rich context from which learners' perspectives of language teacher leadership can be examined.

\section{METHODOLOGY}

The exploratory nature of this study lent itself best to qualitative research methods since the research design contained no pre-existing framework and was left open and flexible in order to respond to new directions that may emerge during the research process (Dörnyei, 2007). Additionally, as the purpose of this study was to examine how learners view language teachers as leaders, a qualitative approach allowed for the researchers to investigate the issue in a descriptive manner and present the findings through the learners' own words.

Data analysis procedures followed the general principles of Grounded Theory (Charmaz, 2006) in which emergent trends and phenomena within the data were inductively identified and coded for further examination and interpretation.

\section{Participants}

With the previously discussed range of possible influences on how overall leadership is perceived in the country, this study chose to investigate university students' views of language teacher leadership for the following reasons: 1) they are presumably old enough to maturely discuss issues of leadership; 2) they have had years of experience as English language learners (formally starting to study English in the $3^{\text {rd }}$ grade); and 3) most have been exposed to various English language teachers, in various contexts, at various ages. This allows the sample group to draw from a rich experiential background (both as language learners and citizens of Korea) when discussing the leadership qualities of language teachers. 
The volunteer participants for this study were 20 Korean undergraduate language learners from 3 different universities in Korea who had at least reached an intermediate proficiency level in English (CEFR, level B1). The convenience sample group consisted of 12 males and 8 females ranging in age from 20 to 26 years old. Eleven of the participants were English majors in their second to fourth year of study and were taking both English proficiency and linguistics courses as part of their undergraduate requirements. The remaining 9 participants were taking university English language proficiency courses but were not English or English Education majors. All participants had had at least 10 years of English language learning experience and had taken classes with both local and foreign teachers in public and private educational settings.

\section{Data collection}

Prior to formal data collection, the interview schedule (Appendix A) was piloted with 3 participants to ensure the answers elicited were in line with answering the research questions. The piloting confirmed the validity of the interview questions, and formal data collection commenced with the same interview schedule. As Kvale (2008) describes, "In common interview studies, the number of interviews tends to be around $15 \pm 10$ " (p. 64); thus interviews were initially scheduled with a total of 15 participants; however, an additional 5 interviews were conducted in order to reach a point of saturation (Kvale, 2008; Seidman, 2013). Data was collected over the course of two months in individual single-session semi-structured interviews. Respecting the participants as second language learners of English and acknowledging the difficulty and anxiety they may have about being interviewed, participants were free to interact in English, Korean, or both. All participants interacted predominantly in English with Korean only being used when a participant had difficulty explaining something, or an English word equivalent was not readily available. Written informed consent was gathered prior to conducting each interview. A semi-structured interview format was chosen to allow for freedom and flexibility within responses (Berg, 2001), and to provide the opportunity for the researchers to go beyond the answers to prepared questions by encouraging participants to "elaborate on issues raised in an exploratory manner" (Dörnyei, 2007, p.136). The semi-structured format also enabled the researchers to clarify participants' answers and request further detail, which contributed to a richer data set.

\section{Data analysis}


In order to cross-analyse the data for overall accuracy and consistency, the data analysis procedures began with the researchers separately listening to the interview recordings and transcribing participants' responses for each interview question. Any Korean words that existed within the interviews were translated and cross-checked with a bilingual speaker to ensure accuracy. The transcripts were then compared and combined for further analysis. Following the interview transcription, standard primary cycle coding procedures were followed in which the data were examined for similarities and differences, and arranged under general headings (Tracy, 2013) using Nvivo 10 software.

The primary emerging categories became teacher leadership practices and teacher leadership characteristics. During secondary cycle coding, the preliminary codes were critically analysed to synthesize the data into emergent themes (Tracy, 2013). During this process, data were reorganized and grouped under subheadings within the preliminary categories. In an additional tertiary level of coding, the data were redistributed into interpretive categories that captured the overarching core qualities of teacher leadership. Throughout the coding process, data were under constant comparison and review by both researchers, and researchers were in constant contact to monitor coding reliability. This resulted in the data being reorganized and re-categorized multiple times to capture the emergent trends (Charmaz, 2006). For all emergent themes, data were further reviewed to extract direct quotes that supported each theme. For all direct quotes used in this study, interview recordings were revisited, and participants' words were transcribed verbatim. Three dots (...) appearing in the interview excerpts in the following sections represents a pause in the response and/or thinking time. To ensure the anonymity of participants and their responses, each respondent has been given a pseudonym.

\section{FINDINGS}

\section{Research question 1: In what ways do learners see language teachers as leaders?}

From the data collected, it was apparent that learners' ideas of good language teacher leadership differed from their perception of good leaders in a general sense. Responses to the first interview question, which asked participants to describe a person that they felt was a good leader (not necessarily a teacher), were typically about a person in some direct or relational position of authority (e.g. platoon leader, cooking instructor), older relatives (e.g. parent, grandparent), and occasionally an esteemed public figure (e.g. political leader, celebrity). These responses strongly 
relate to Confucian values that exist within the country that inherently link leadership to those higher in age, status, and position (Lee, 2001). However, when leadership was put in the context of language teaching, the specified qualities and characteristics were quite different. The heavy focus on test preparation from middle school onward and the resultant authoritative, top-down, teacher-centred lessons were raised in a number of interviews as being at odds with a paradigm of leadership conducive to the language classroom. In line with arguments proposed by Underhill (2005), in this study, learners' ideas of leadership seemingly depart from the hierarchical, authoritative leadership structure that is typically applied to the Korean education climate. This suggests that language teacher leadership may transcend the boundaries of traditional leadership notions and/or operate within different parameters of the cultural conceptualization of leadership. It may also imply that, as one participant, Sumin, put it, "Language teaching is a different kind of leadership"

The difference among participants' concepts of leaders in a general sense and language teacher leadership was particularly apparent in their responses to the question, Do you think of language teachers as leaders? Thirteen participants responded without hesitation that they indeed consider language teachers to be leaders; however, seven initially responded "no" or "not really".

When prompted 'why do you not see language teachers as leaders?' the participants gave the following reasons. Donghyeon, Woomin, and Minjin all attested that from their experience, most language teachers in Korea just read from the book or lectured. They commented that because of the way class was conducted, 'communication' in the classroom is typically too unidirectional and teacher focused to be considered leadership. Minsu stated that leadership involves inspiring students to follow; however, the heavy focus on high-stakes testing objectives make it difficult. Jaeseung felt that teachers can be leaders by "motivating instead of just pushing students," but that, from his experience, most simply did the latter. Similarly, Minjae felt that a good teacher-leader needed charisma that would inspire students to learn, but he had yet to meet such a teacher as most were primarily concerned with transmitting information. These comments seem to suggest that leadership goes beyond positional status when it comes to learners viewing a language teacher as a leader.

We must note that as each of the interviews progressed, all participants that originally stated that they did not really see language teachers as leaders were able to discuss leadership qualities that they felt could, and should, relate to language teachers, which are presented and discussed below. 


\section{Research question 2: From the learners' vantage point, what specific (personal and pedagogical) features and characteristics contribute to good language teacher leadership?}

In the following sections, we detail the specific personal and pedagogical features and characteristics that the learners in this study believe to contribute to good language teacher leaders. The elicited characteristics of good language teacher leadership are presented under the thematic subheadings of Passion, Rapport, Purpose, and Balance \& Flexibility, which were the final interpretive themes that resulted from the formal data analysis and coding procedures previously outlined.

It is important to note that the themes presented in this paper are interpretive and therefore are intended to posit a general formulation of the emergent themes, rather than directly invoking any existing leadership theory or model. How themes are described, conveyed, and positioned by students' responses in this study embodies the uniqueness of the concept of leadership to the language learning classroom. It is also important to caution that the researchers do not propose these categories as definitive qualities of good language teacher leadership; rather these categories are used essentially as a means to discuss the emergent leadership components in an organized manner. Excerpts from interviews are provided throughout this section to illustrate the types of responses that were elicited for each emergent trend.

Passion. The first theme, passion, contains responses which reference good language teacherleaders as charismatic, confident individuals who are deeply engaged in the profession of teaching, concerned with their own growth and the growth of their students, and are motivated by an intrinsic sense of responsibility to the students and the joy and satisfaction that comes from the process of teaching and learning. In essence, these teachers lead by example and provide a good role model for learners to follow which can energize and motivate their students. This is illustrated in the following interview excerpt from Miyoung.

Have passion and love your job, that job means teaching and have responsibility... because that.. if we students saw that passion, love, responsibility then we will be motivated .. yes.. and try to keep that motivating in hard studying. 
Participants explained that passionate teachers exude enthusiasm and help motivate their students, aiming to instil within them an interest in the language, confidence, and a positive attitude towards learning, which can extend far beyond the classroom. Minjun explained:

I think so many... so many professors or teachers are focused on more information, more data, but when students are really really interested in ... in some foreign language they will learn by themselves ... so of course information, ... guidelines and guidance will be important but more than that I think as a leader professor can be... can influence and can inspire the students who will eventually may become a nerd in some language ...

Additionally, many participants expressed that teachers who exhibit passion for their job and a dedication to constant development and improvement are good language teacher leaders. As outlined by Sohee:

If I am a student I think wow she is so passionate for teaching English... If they don't have passion of teaching, they can't develop their knowledges or way of teaching I think because they just satisfied to become a teacher and they teach and teach again same way I think; so we need passion.

However, it is not simply about possessing a passion for teaching, but also about conveying this passion to students and being a good model for them to follow. As Suyoung stated:

...someone who shows their passion and love through their teaching, it means their passion and love are visible so students can receive it and move it to their study.

For students, it seems that passion is manifest through a teacher's self-driven commitment to developing and expanding their own professional knowledge, expertise, and practices. It is exuded through a teacher's active expression of their genuine interest in the subject matter and in their classroom instruction, and positively impacts students' feelings of motivation and inspiration in language learning.

Rapport. In the theme rapport, references to good language teacher leadership relate to the positive connection and communication among people (teacher and learners) and the capacity to lead, manage, and develop an active learning community through respect, empathy, kindness, and by building and maintaining positive relationships. Some participants in this study believed rapport and communication to be essential leadership capacities, indicating that good language teacher leadership is co-constructed between the teacher and learners, and is something that cannot exist without positive interaction. As Minjun stated: 
Interacting with students, umm dialogue... a dialogue by itself signifies interaction and communication should be based upon interaction rather than lecturing lecturing lecturing, I'm the greatest professor in the world... I think ...it may be efficacious to be more friendly and amicable to make a good relationship.

The significance placed on active, two-way communication between a teacher and their learners was ubiquitous throughout the data. Participants commonly expressed that a good language teacher leader listens to and is genuinely receptive to their students' thoughts and opinions. Sohee outlined her thoughts on the importance of this quality:

I think all teachers can be leaders, but not all teachers are leaders. I think maybe they should be listening to their students carefully and like I said before, they should motivate students, not force or be pushy to them.

Participants communicated that a good language teacher leader establishes and maintains a controlled learning atmosphere in which learners feel supported and connected, being mindful of not making them feel pushed, pressured, or nervous. Minjin vividly recalled his feelings of apprehension because of the teacher's assertive demeanour and countered with his idea of what leadership should involve:

I'm not follow the teacher but just obey the teacher because he has a punishment when we do not memorize all the words or sentence, so yeah, I feel a little scary of the teacher, can't even talk, too scary . . .I think that leadership is all member of, maybe the student, want to do, but punish to push the student is not making the student really want to do.

Making students feel comfortable, appreciated, and confident requires that teachers get to know and understand learners as individuals and seek to develop a relationship based on comity and trust (Underhill, 2005). Donghyeon exemplified this point when discussing his experience with a language teacher that he felt was a good leader:

He keep saying, you are really doing good, your English is really perfect, so I feel am I? Are you serious? He give me confidence. And I have any questions he answer me really truly I mean he really care my question, my situation so I feel he is really interesting in me.

For the language learners in this study, good teacher leadership is about the ability to manage people through positive relationships rather than through authority. Rapport is created by engaging students in learning and communicating with them throughout the learning process. Further, by listening earnestly to students and being supportive rather than overly 
assertive, a teacher can help students feel more autonomous, comfortable, and confident in future undertakings. Kyung offered this advice to teachers interested in being better leaders:

Ask a lot of questions. Meet students after class and ask about their problems, not just related to teaching, but anything they want to talk about. Obviously be friendly because just smiling is not enough.

Kyung's comment synthesizes several of the components of rapport addressed above. First, it emphasizes that two-way communication demonstrates a teacher's genuine concern for each individual student and their willingness to help students when needed. Secondly, it infers that trust is built when students feel supported and appreciated. Finally, it asserts that talking to students about their challenges can galvanize their efforts and help build their confidence.

Purpose. The theme purpose includes responses in which participants mentioned a good language teacher leader as being prepared, being oriented towards helping learners achieve their goals, delivering clear/purposeful lessons, and teaching because it gives them personal and professional fulfilment. Further, participants stressed that good teacher-leaders seem be self-driven by a desire to be a great teacher above all else. Several participants stated that they could clearly recognize when their teachers have a sense of professional purpose, and when they do not. Dongmin lamented that:

[Some teachers] were just there to earn money, so that was a problem, I think. And they didn't have the ability to teach students.

Participants also mentioned that a teacher's sense of purpose needs to be exteriorized through an enduring commitment to helping students achieve their goals. In the act of sharing their purpose through their teaching practices, actions, and attitude, they engage students and inspire them to create their own sense of purpose. Jihun explained:

Ifelt ... (this teacher was a) great leader because he always prepare many thing to class ...so I feel that he tried to do something to teach students... and then also he always smiling... he tried to teach more and more something I think ...

Additionally, teachers with purpose exude a sense of commitment and responsibility to their work which fosters learners' assurance and trust in them. Jaekwong affirmed that: 
... teachers make students believe language teachers well. I mean, students have to have confidence about their language teachers. Like, "my teachers really good at teaching.

From the students' perspective, it seems that purpose is conceptualized not necessarily as teaching ability, but as a desire to demonstrate professionalism through effort and sincerity. It is also exemplified through encouraging and empowering students to achieve their full potential and to enact their own sense of purpose.

Balance \& Flexibility. In the final theme balance \& flexibility, references to good language teacher leadership relate to a teacher's ability to balance various aspects of the environment and teaching processes through a flexible mindset, and flexible teaching approaches. Participants commonly gave reference to good leaders being able to balance between challenging their students and making the class enjoyable as exemplified in the following interview excerpt from Minjae.

In many case professors (have) different styles... But good leaders make a fun, enjoyable language class. It is important because language subject is usually boring subject...it is important balance sometimes enjoyable and sometime hard work.

Additionally, many participants voiced that good language teacher leaders are flexible in lesson planning and delivery, experiment with new modes of learning, infuse the lessons with humour and novelty, and invite students to share in leadership responsibilities. Jaekwong provided an example of his language teacher displaying good leadership skills:

He taught not in the book, he used different ways... he always find some good materials for improve my English speaking, so he always find somewhere not in the textbook, additional materials. ... He asked me first about the course, after every week, how was this week's course, he always get my feedback, this part is boring and he changed another part.

Although it is not always possible for teachers to experiment with novel materials, activities, and teaching techniques because learning objectives may determine to some extent what they teach and how they teach it, a good teacher considers students' opinions and is willing to make reasonable adjustments where possible. While Jaekwong alluded to the belief that good teacherleaders will seek students' input and feedback, Sohee stated it more explicitly: 
Change your way of class more interesting or ask students how to . . how good the class was ... what they want... and try to change her or his class...after then, study more their way of teaching.

Thus, components of balance \& flexibility indicate that the teacher is concerned with students as individuals, is willing to adapt to various learning styles and needs, and can find an effective balance between work and fun and between covering content requirements and integrating novel approaches. Moreover, flexible teachers query their students' feelings about their learning processes and progress and make appropriate and beneficial adjustments based on students' feedback.

\section{The interaction and overlap of Passion, Rapport, Purpose, and Balance \& Flexibility}

The researchers acknowledge that the language teacher leadership characteristics elicited do not necessarily fit neatly into one category or another as proposed above. As previously stated, these categories were used for initial presentation of the data; however, it is now important to discuss how these characteristics overlap, interact amongst one another, and work together in the formation of language teacher leadership from the point of view of learners.

A commonly shared theme permeating all of these categories is the importance levied on personal characteristics, and the way that teachers conduct themselves inside and outside the classroom. This suggests that it is the way that teachers act and interact with students' (possibly more than the way that they instruct their classes) that influences learners' perceptions of their leadership capacity, once again indicating that good leadership is more than just good teaching practices. For example, there were frequent references to teachers being a good model for learners in several ways, including as an L2 model, as a learner model, as a motivational model, as a communicative model, and as a model of cross-cultural global interaction which do not fit into a single specific category but rather encompass elements of all four themes; passion, rapport, purpose, and balance \& flexibility. Additionally, many of the interview excerpts presented in the above categories do in fact contain overlapping elements and characteristics of other categories. Thus, the categories of passion, rapport, purpose, and balance \& flexibility should be viewed and treated as dynamic and interactive rather than absolute. 


\section{DISCUSSION}

From the variation within and amongst participants' responses in the above categories, it was clear that good language teacher leadership departs from authoritative leadership practices and the structural hierarchy of leadership in the Korean education system. This means that classroom teachers, despite not possessing a role traditionally perceived as a leadership position in the Korean educational system, can be, and indeed often are, seen as leaders by their students. Good language teacher leadership from the learners' perspective also extends beyond the ideas of leadership from a traditional teaching/ teacher sense (Greenier \& Whitehead, 2016), and beyond just good teaching pedagogy in the classroom. The data suggest that for a language teacher to be perceived as a good leader by students, they must possess various leadership qualities. However, it is not just the individual characteristics alone that are important in the perception of a good leader. Good language teacher leadership is suggested to emerge from the inter-relationship and interaction between the various characteristics with the common goal of fostering positive feelings towards language learning and engaging and motivating learners to develop themselves (linguistically and personally) both inside and outside the classroom. What students see as good language teacher leadership seems to have less to do with a teacher's capacity to complete predetermined learning objectives or reach specific targets of learning, and more to do with the fostering of students' interpersonal and intellectual development through positive relationships with their teachers. The participants in this study point to the difference between managing students' learning and instilling within students the confidence and satisfaction of learning for themselves.

Thus, throughout the themes of passion, rapport, purpose, and balance \& flexibility, core principles of already existing leadership models are evident. For example, servant leadership stresses the need to put those served first and to ensure they grow as individuals. It also puts the primary focus on the development and prosperity of those in the community by helping each individual grow to their full potential. Transformational leadership calls on the leader to inspire, to engender confidence and motivation in learners, and to share in the learning journey. It also compels the leader to impart with clarity a shared vision, to offer support and perpetual encouragement (intellectual stimulation), and to give consideration to individual needs. Authentic leadership requires sincere action so that the trust of followers is based on integrity and credibility and not power, while acting with compassion and developing relationships based on mutual trust and respect. It also obligates the leader to understand their own strengths and weaknesses, which will enhance their confidence and self-esteem, consequently making them "more comfortable 
forming transparent, open, and close relationships with others" (Walumbwa et al., 2008, p. 93). Distributed leadership underscores interaction and interdependence as essential for success in any organizational environment. It places expertise at the foundation of leadership and assumes the environment is built upon a shared responsibility for communication and continuous development (Harris, 2013). The definition of leadership in ELT proposed by Underhill (2005) also highlights lifelong learning, and Bailey (2008) posits that it is the fulfilment gained from helping others succeed that keeps many teachers in the profession.

Thus, the data imply that good language teacher leaders possess a combination of qualities and characteristics from various leadership models that take learners beyond classroom, course, and administrative objectives. From the learners' vantage point, although good language teacher leadership may include characteristics of good pedagogy, a good language teacher leader is able to take the learning process further by reaching students on an individual level, encouraging them to persist throughout the language learning process, and instilling within them leadership qualities and experiences that can positively affect them beyond the context of language learning.

With so much variation in students' responses, it is clear that language teacher leadership cannot be placed into one-size-fits-all definition, as concepts of a good leader can vary based on individual preferences. However, a feature of leadership that was shared amongst participants is that leadership in language teachers is not about a specific set of qualities, but rather the interaction of various qualities, characteristics and techniques within the themes of passion, rapport, purpose, and balance \& flexibility that are utilized by the teacher to inspire them both as language learners and individuals. Thus, the findings of this study suggest that language teacher leadership is something that should be viewed as both complex and dynamic and therefore as something that emerges through characteristics and practices exhibited by a teacher within a specific teaching context.

Although traits and practices within the themes presented in this study are contributory factors in language teacher leadership, it is important to note that the researchers do not intend to delimit the characteristics perceived by learners within these categories - further research needs to be done to explore additional characteristics that may support (or inhibit) teacher leadership in the ELT context. 


\section{CONCLUSIONS}

Although good teaching practices and good leadership undeniably relate to one another, the findings in this study point to qualitative differences that separate them. Students' responses that referenced good teaching practices as aspects of language teacher leadership tended to be connected directly to learning and learning objectives. This included features like employing effective management, determining and reaching lesson objectives, and developing learners' skills. However, the leadership traits mentioned within the categories of passion, rapport, purpose, and balance \& flexibility went beyond good teaching techniques and practices and focused on the humanistic qualities of teachers. These leadership traits transcended the immediate connection to learning and learning objectives at the classroom level and involved stimulating learners in the overall process of language learning inside and outside the classroom.

Thus, amidst the great variation that was found to exist between learners in regards to how they perceive and describe language teacher leadership, as a whole, participants tended to give more attention to the personal attributes of teachers and their ability to inspire, motivate, and engage learners in the learning process rather than the organizational, managerial, and pedagogical attributes of leadership on which teachers tended to focus (Greenier \& Whitehead, 2016). Thus, we argue that while it is possible to be a skilled and knowledgeable teacher without leadership competency, the data collected in this study seem to indicate that students do intuitively recognize the differences between good teachers and good teachers who are also good leaders.

This study aimed to further the understanding of both what it means and what it takes to be a better leader in the language classroom from the learners' perspective. The findings of this study have shown the complexity of language teacher leadership and some of the key principles that factor into its construction. Beyond the field of language teaching, it would be interesting and informative to examine various perspectives on leadership, particularly that of the learners (the primary consumers of higher education) in other academic disciplines, such as the humanities, social sciences, business, law, creative arts, and others. Evaluating the topic of teacher leadership in other subject areas may yield significant findings regarding crucial differences in the disciplines, as well as compelling, overlapping elements that could help formulate a more broadly applicable conceptualisation of leadership in teaching practice.

Additionally, exploring teacher leadership in ELT in a broader range of contexts (e.g., different countries, types of programs and teaching approaches, and perspectives from various stakeholders) 
and determining more precisely defined variables (e.g., different ages, L1 backgrounds, L2 proficiencies, gender, and years of language learning experience) would be greatly beneficial in furthering and refining the understanding of the concept.

The increasing dedication to leadership and enhancing professionalism in ELT signals a growing consensus of the need for further development of leadership in language teaching. To a greater extent than ever before, teachers are preparing to take a larger role in the decisions that affect them and their students; this requires bolstering teachers' capacity to best serve a growing diversity of learners while supporting them in ever-expanding roles in their schools and communities (Fenner, 2016). The students' views voiced in this study have shed light on some of the teacher leadership qualities that play an important role in their learning and development. However, to enhance teacher leadership potential, and to make it a more integral component of teacher education, training, and professional development, it is imperative for further work to be done in the field to gain a better and fuller understanding of what it means and what it may entail for different stakeholders across a variety of contexts.

\section{THE AUTHORS}

George E. K. Whitehead is an assistant professor in the Graduate School of TESOL at Hankuk University of Foreign Studies, South Korea. His main research interests include language teacher education and development, language teacher leadership, critical L2 pedagogy, and the development of context specific language teaching and learning practices.

Vincent Greenier holds a PhD in Language Teaching and Learning from The University of Auckland. He is presently a lecturer at the University of Aberdeen in Scotland. His main research interests are creative approaches to language teaching, teacher leadership, curriculum and materials design, and innovate approaches to qualitative research.

\section{REFERENCES}

Ackerman, R., \& Mackenzie, S. V. (2006). Uncovering teacher leadership. Educational Leadership, 63(8), 66-70. 
Anderson, M. (2017). Transformational leadership in education: A review of existing literature. International Social Science Review, 93(1), 4.

Anderson, N. J. (2009). Leading from behind. In M.A Christison \& D.E. Murray (Eds.), Leadership in English language education: Theoretical foundations and practical skills for changing times (pp. 110-122). New York, NY: Routledge.

Baecher, L., Knoll, M., \& Patti, J. (2013). Addressing English language learners in the school leadership curriculum: Mapping the terrain. Journal of Research on Leadership Education, 8(3), 280-303. doi:10.1177/1942775113498377

Bailey, K. (2008). Passing on the light: Encouragement as a leadership skill. In C. A. Coombe, L. McCloskey, L. Stephenson, \& N. J. Anderson (Eds.), Leadership in English language teaching and learning (pp. 29-37). Ann Arbor, MI: University of Michigan Press.

Bass, B. M. (1985). Leadership and performance beyond expectations. New York, NY: Collier Macmillan.

Begley, P. T. (2001). In pursuit of authentic school leadership practices. International Journal of Leadership in Education, 4(4), 353-365. doi:10.1080/13603120110078043

Berg, B. L. (2001). Qualitative research methods for the social sciences (4th ed.). Boston, MA: Allyn and Bacon.

Berry, B., Daughtrey, A., \& Wieder, A. (2010). Teacher leadership: Leading the way to effective teaching and learning. Center for Teaching Quality. Retrieved from https://files.eric.ed.gov/fulltext/ED509719.pdf

Bhindi, N., \& Duignan, P. (1997). Leadership for a new century: Authenticity, intentionality, spirituality and sensibility. Educational Management \& Administration, 25(2), 117-132. doi:10.1177/0263211x97252002

Bush, T., \& Glover, D. (2014). School leadership models: What do we know?. School Leadership \& Management, 34(5), 553-571. doi: 10.1080/13632434.2014.928680

Carpenter, B. D., \& Sherretz, C. E. (2012). Professional development school partnerships: An instrument for teacher leadership. School-University Partnerships, 5(1), 89-101.

Charmaz, K. (2006). Constructing grounded theory: A practical guide through qualitative research. London, UK: Sage.

Cheng, B. S., Chou, L. F., Wu, T. Y., Huang, M. P., \& Farh, J. L. (2004). Paternalistic leadership and subordinate responses: Establishing a leadership model in Chinese organizations. Asian Journal of Social Psychology, 7(1), 89-117. doi:10.1111/j.1467-839X.2004.00137.x

Cho, Y., \& Bong, H. C. (2013). Trends and issues in action learning practice: Lessons from South Korea. New York, NY: Routledge. 
Choi, I. C. (2008). The impact of EFL testing on EFL education in Korea. Language Testing, 25(1), 39-62. doi:10.1177/0265532207083744

Christison, M., \& Lindahl, K. (2009). Leadership in public school environments. Leadership in English language education: Theoretical foundations and practical skills for changing times, 50-73. doi:10.4324/9780203077009

Christison, M., \& Murray, D. E. (2009). Leadership in English language education: Theoretical foundations and practical skills for changing times. New York, NY: Routledge.

Clandinin, D. J., \& Connelly, F. M. (1995). Teachers' professional knowledge landscapes. New York, NY: Teachers College Press.

Coombe, C., McCloskey, M., Stephenson, L., \& Anderson, N. (2008). Leadership in English language teaching and learning. Ann Arbor, MI: University of Michigan Press.

Creswell, J. W., \& Creswell, J. D. (2017). Research design: Qualitative, quantitative, and mixed methods approaches. Thousand Oaks, CA: Sage publications.

Crowther, F., Ferguson, M., \& Hann, L. (2009). Developing teacher leaders: How teacher leadership enhances school success. Thousand Oaks, CA: Corwin Press.

Cumings, B. (2005). Korea's place in the sun: A modern history (Updated). New York, NY: WW Norton \& Company.

Curtis, R. (2013). Finding a new way: Leveraging teacher leadership to meet unprecedented demands. Retrieved from www.aspeninstitute.org/education

Dimmock, C., \& Walker, A. (2005). Educational leadership: Culture and diversity. Thousand Oaks, CA: Sage.

Dörnyei, Z. (2007). Research methods in applied linguistics: Quantitative, qualitative, and mixed methodologies. Oxford, UK: Oxford University Press.

Fenner, D. S. (2016). The preparation of the ESL educator in the era of college-and-career readiness standards. Retrieved from https://www.tesol.org/docs/defaultsource/advocacy/ccr-standards-convening_final2.pdf?sfvrsn=2.

George, B. (2010). True north: Discover your authentic leadership. Hoboken, NJ: John Wiley \& Sons.

Greenier, V. T., \& Whitehead, G. E. K. (2016). Towards a model of teacher leadership in ELT: Authentic leadership in classroom practice. RELC Journal, 47(1), 79-95. doi: $10.1177 / 0033688216631203$

Greenleaf, R. (2007). The servant as leader. In W. C. Zimmerli, K. Richter, \& M. Holzinger (Eds.), Corporate ethics and corporate governance (pp. 79-85). Berlin, DE: Springer.

Hargreaves, A., \& Fink, D. (2004). The seven principles of sustainable leadership. Educational Leadership, 61(7), 8-13. doi:10.12691/education-4-2A-6 
Harris, A. (2013). Distributed school leadership: Developing tomorrow's leaders. New York, NY: Routledge.

Johnson, K. E., \& Ma, P. (1999). Understanding language teaching: Reasoning in action. Boston, MA: Heinle \& Heinle Publishing.

Judge, T. A., \& Piccolo, R. F. (2004). Transformational and transactional leadership: a metaanalytic test of their relative validity. Journal of applied psychology, 89(5), 755-768. doi:10.1037/0021-9010.89.5.755

Katzenmeyer, M., \& Moller, G. (2009). Awakening the sleeping giant: Helping teachers develop as leaders. Thousand Oaks, CA: Corwin Press.

Kiersch, C., \& Peters, J. (2017). Leadership from the inside out: Student leadership development within authentic leadership and servant leadership frameworks. Journal of Leadership

Education, 16(1). doi:10.12806/V16/I1/T4

Killion, J., \& Harrison, C. (2006). Taking the lead: New rules for teachers and school-based coaches. Oxford, OH: Learning Forward.

Kim, D. J., \& Kwan, O. (2002). Washback on 12th grade English classes of the English tests within Korean university entrance exams. English Education, 57(3), 303-331.

Kumaravadivelu, B. (2008). Cultural globalization and language education. London, UK: Yale University Press.

Kvale, S. (2008). Doing interviews. Thousand Oaks, CA: Sage.

Lee, J. K. (1999). Historic factors affecting educational administration in Korean higher education. Higher Education Review, 32(1), 7.

Lee, J. K. (2001). Confucian thought affecting leadership and organizational culture of Korean higher education. Radical Pedagogy, 3(3). Retrieved from https://files.eric.ed.gov/fulltext/ED504451.pdf

Lee, J.K. (2006). Educational fever and South Korean higher education. Revista Electronica de Investigacion Educativa, 8(1). Retrieved from https://files.eric.ed.gov/fulltext/ED491564.pdf

Leithwood, K., Mascall, B., \& Strauss, T. (Eds.). (2009). Distributed leadership according to the evidence. New York, NY: Routledge.

Lieberman, A., \& Miller, L. (2004). Teacher leadership. San Francisco, CA: Jossey-Bass.

Lightbown, P. \& Spada, N. (2001). Factors affecting second language learning. In C. Candlin \& N. Mercer, English language teaching in its social context: A reader (1st ed., pp. 28 43). New York, NY: Routledge. 
Margolis, J., \& Huggins, K. S. (2012). Distributed but undefined: New teacher leader roles to change schools. Journal of school leadership, 22(5), 953-981. doi:10.1177/105268461202200506

McGee, A., Haworth, P., \& MacIntyre, L. (2015). Leadership practices to support teaching and learning for English language learners. TESOL Quarterly, 49(1), 92-114. doi:10.1002/tesq. 162

Moodie, I., \& Nam, H. J. (2016). English language teaching research in South Korea: A review of recent studies (2009-2014). Language Teaching, 49(01), 63-98. doi:10.1017/S026144481500035X

Muijs, D., \& Harris, A. (2003). Teacher leadership - Improvement through empowerment: An overview of the literature. Educational Management \& Administration, 31(4), 437-448. doi:10.1177/0263211x030314007

Murphy, J. (2005). Connecting teacher leadership and school improvement. Thousand Oaks, CA: Corwin Press.

Pennington, M. C., \& Hoekje, B. J. (2010). Language program leadership in a changing world: An ecological model. (Vol. 1). Bingley, UK: Emerald.

Robertson, P. (2002). The pervading influence of Neo-Confucianism on the Korean education system. Asian EFL Journal, 4(2), 1-11.

Seidman, I. (2013). Interviewing as qualitative research: A guide for researchers in education and the social sciences. New York, NY: Teachers college press.

Shields, C. M., \& Sayani, A. (2005). Leading in the midst of diversity. In F. English (Ed.), The Sage handbook of educational leadership. Advances in theory, research, and practice (pp. 380-402). Thousand Oaks, CA: Sage Publications.

Stephenson, L. (2008). Leadership theories, educational change and developing a learning organization. In C. A. Coombe, L. McCloskey, L. Stephenson, \& N. J. Anderson (Eds.), Leadership in English language teaching and learning (pp. 7-16). Ann Arbor, MI: University of Michigan Press.

Telles, J. A. (2000). Biographical connections: experiences as sources of legitimate knowledge in qualitative research. International Journal of Qualitative Studies in Education, 13(3), 251-262. doi:10.1080/09518390050019668

Tracy, S. J. (2013). Qualitative research methods. West Sussex, UK: Wiley-Blackwell.

Underhill, A. (2005). Learning leadership and ELT today. Humanising Language Teaching. 7(1). Retrieved from http://www.hltmag.co.uk/jan05/mart01.htm

Vernon-Dotson, L. J., \& Floyd, L. O. (2012). Building leadership capacity via school partnerships and teacher teams. The Clearing House: A Journal of Educational Strategies, Issues and Ideas, 85(1), 38-49. doi:10.1080/00098655.2011.607477 
Walumbwa, F. O., Avolio, B. J., Gardner, W. L., Wernsing, T. S., \& Peterson, S. J. (2008). Authentic leadership: Development and validation of a theory-based measure. Journal of management, 34(1), 89-126. doi:10.1177/0149206307308913

Watt, K. M., Mills, S. J., \& Huerta, J. (2010). Identifying attributes of teacher leaders within the advancement via individual determination program: A survey of school principals. Journal of school leadership, 20 (3), 352-368. doi:10.1177/105268461002000305

Wei, M., Den Brok, P., \& Zhou, Y. (2009). Teacher interpersonal behaviour and student achievement in English as a Foreign Language classrooms in China. Learning Environments Research, 12(3), 157-174.

Wenner, J. A., \& Campbell, T. (2017). The theoretical and empirical basis of teacher leadership: A review of the literature. Review of Educational Research, 87(1), 134-171. doi:10.3102/0034654316653478

Wheeler, D. W. (2011). Servant leadership for higher education: Principles and practices. San Francisco, CA: John Wiley \& Sons.

White, R., Hockley, A., van der Horst Jenson, J., \& Laughner, M. S. (2008). From teacher to manager: Managing language teaching organizations. Cambridge, UK: Cambridge University Press.

Whitehead, G. E. K. (2016). The rise and fall of the National English Ability Test: Examining Korean high school English teachers' perspectives. Asian EFL Journal, 18(4), 124-155.

Wong, K. C., \& Evers, C. W. (2001). Leadership for quality schooling: International perspectives. Thousand Oaks, CA: Routledge.

Wubbels, T., Brekelmans, M., den Brok, P., \& van Tartwijk, J. (2006). An interpersonal perspective on classroom management in secondary classrooms in the Netherlands. In C. M. Evertson \& C. S. Weinstein (Eds.), Handbook of Classroom Management: Research, Practice, and Contemporary Issues (pp. 1161-1191). New York, NY: Lawrence Erlbaum.

Yi, M., \& Douglas, W. A. (1967). Korean Confucianism today. Pacific Affairs, 40(1/2), 43-59. doi:10.2307/2754621

York-Barr, J., \& Duke, K. (2004). What do we know about teacher leadership? Findings from two decades of scholarship. Review of Educational Research, 74(3), 255-316.

doi:10.3102/00346543074003255

\section{APPENDIX A}

Interview Schedule 
1. When you think of a good leader (famous person, friend, parent, teacher, etc.) who comes to mind? What makes/made them a good leader?

2. Do you think of language teachers as leaders?
a) If yes, in what ways?
b) If no, why not?

3. Can you tell me about a language teacher who you felt was a good leader?
a) What made them a good leader?
b) Personal traits: describe
c) Teaching traits: describe
d) Other: describe

4. Can you think of a specific lesson where you really felt a teacher showed good leadership? Or hypothetically; what could a teacher do during a lesson that would impress you in terms of leadership.

5. What advice would you give to language teachers to help them be better leaders in the classroom - especially for new teachers?

6. Is there anything else you would like to share or that you would like me to know? 